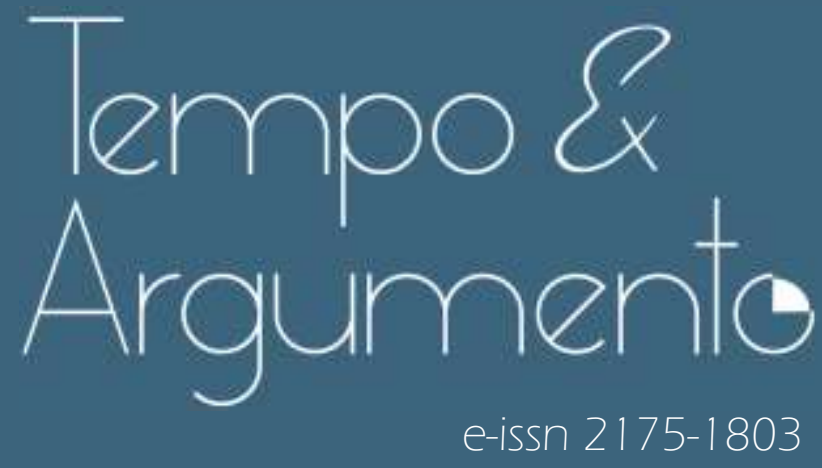

\title{
Authoritarian setback in the current crisis of Brazilian democracy
}

- Emerson Gabardo

Ph.D. in Public Law at Federal University of Paraná (UFPR).

Professor of Administrative Law at the Pontifical Catholic University of Parana.

Professor in the Department of Public Law at Federal University of Parana.

Curitiba, PR - BRAZIL

lattes.cnpq.br/3091904591160385

emerson.gabardo.br@gmail.com

(D) orcid.org/0000-0002-1798-526X

- Marion Brepohl

Ph.D. in History at University of Campinas (UNICAMP).

Professor in the Department of History at Federal University of Parana.

Curitiba, PR - BRAZIL

lattes.cnpq.br/2049493954300365

mbrepohl@yahoo.com.br

(D) orcid.org/0000-0002-6556-6019

- Marcos Gonçalves

Ph.D. in History at Federal University of Paraná (UFPR).

Professor in the Department of History at Federal University of Parana.

Curitiba, PR - BRAZIL

lattes.cnpq.br/9200219455621383

paideia_mg@yahoo.com.br

(1) orcid.org/0000-0002-9101-9780

To cite this article (ABNT):

GABARDO, Emerson; BREPOHL, Marion; GONÇALVES, Marcos. Authoritarian setback in the current crisis of Brazilian democracy. Tempo e Argumento,

Florianópolis, v. 13, n. 34, e304, set./dez. 2021.

do) http://dx.doi.org/10.5965/2175180313342021 e0304

Received on 30/08/2020

Approved on 27/07/2021 


\title{
Authoritarian setback in the current crisis of Brazilian democracy
}

\begin{abstract}
The article analyzes the democratic crisis experienced by Brazil from the second decade of the $21^{1 \text { tt }}$ century onwards. The aim is to investigate how this historical period can be characterized. The text asserts that it is inappropriate to understand Brazil without observing its historical distrust of democracy and lack of commitment to the rule of law. The research is based on the assumption that Brazilian modernization in the transition from the $20^{\text {th }}$ to the $21^{\text {st }}$ century was ambiguous but with important achievements. However, the authoritarian mentality and the gap in terms of the quality of political participation are factors of structural permanence. The hypothesis is that Brazil is experiencing a specific moment characterized by the awakening of an authoritarian and conservative mentality that impacts both the State and civil society. The research methodology is based on a bibliographical discussion, with contributions in history, political science, and law. The subjects are discussed in theoretical terms to understand the problems related to the political participation gap, the inequality between citizens, the difficulties of civic culture (mainly in the digital environment), and some inherent weaknesses in democratic performance. Starting from the idea that civic culture influences institutions and these, in turn, impact civic culture, Brazil is currently experiencing a political and cultural setback. Contrary to what could be imagined a few years ago, the process of Brazilian social modernization is threatened in its most important achievements, which implies a danger to the values that sustain democracy.
\end{abstract}

Keywords: authoritarianism; brazilian democracy; political culture; political participation; the rule of law.

\section{Retrocessos autoritários na atual crise da democracia brasileira}

\begin{abstract}
Resumo
O artigo analisa a crise democrática vivida pelo Brasil a partir da segunda década do século XXI. O objetivo é investigar como este período histórico pode ser caracterizado. O texto assevera ser inapropriado entender o Brasil sem observar sua histórica desconfiança na democracia e falta de compromisso com o Estado de Direito. A pesquisa parte do pressuposto que a modernização brasileira na transição do século XX para o século XXI foi um processo ambíguo, porém com conquistas importantes. A mentalidade autoritária e a lacuna em termos de qualidade da participação política, todavia, são fatores de permanência estrutural. A hipótese é que o Brasil está vivenciando um momento específico, caracterizado pelo despertar de uma mentalidade autoritária e conservadora que impacta tanto no Estado quanto na sociedade civil. A metodologia da pesquisa baseia-se em uma discussão bibliográfica, com aportes na história, na ciência política e no Direito. Os assuntos são discutidos em termos teóricos para compreender os problemas relacionados com o hiato de participação política, a desigualdade entre os cidadãos, e as dificuldades da cultura cívica (principalmente no ambiente digital), bem como algumas fragilidades inerentes à própria performance democrática. Partindo da ideia de que a cultura cívica influencia as instituições e estas, por sua vez, impactam a cultura cívica, o Brasil hoje vive um retrocesso político e cultural. Ao contrário do que se poderia imaginar há alguns anos, - processo de modernização social brasileiro está ameaçado em suas conquistas mais importantes, o que implica um perigo aos valores que sustentam a democracia.
\end{abstract}

Palavras-chave: autoritarismo; democracia brasileira; cultura política; participação política; estado de direito. 


\section{Introduction}

After a period of intense strengthening of democracy, economic growth, and social modernization between 1994 and 2014 (AVRITZER, 2018, P. 285), a series of turbulences severely impacted both the Brazilian State and civil society, significantly altering the country's political profile. Several explanatory factors can be mentioned: the substantial evolution of the internet and new disruptive technologies; the excessive expansion of moralist judicial activism with the emergence of charismatic internal leaders; the latest economic crisis; the intensification of a shrill speech against corruption; the decline of the main left party (Workers Party); the rise of the extreme right to power in Brazil (and in some advanced democracies); institutional conflicts between the three branches of government; constitutional amendments and legislative changes that impose sharp social setbacks; widespread public dissatisfaction with politics; and impact of the Covid-19 coronavirus that is causing an unprecedented global situation.

Our research methodology is based on the recent bibliography of Law, Political Science, and History, emphasizing political culture - while recognizing that this is a controversial concept. How to explain political behavior when it always seems more complex than any specific explanation? The notion of "political culture" reappears in French historiography in the 1990 s by applying to the political history of approaches and questions from the social sciences, particularly Political Science. The answer offered by this current implies investigating by considering the system of representations that constitute the identity of the subjects (BERSTEIN, 2009).

Despite the importance of the concept of political culture, there have been recurring questions about accuracy within political science itself. Social institutions and practices in a political system are closely linked to the political culture of a people (ALMOND; VERBA, 1963). One of the criticisms is that the concept can take on a "subjective" character, generating stereotypes about the people that would not happen with ideas resulting from empirical measures. ${ }^{1}$ Some analysts understand political culture as something present in all the characteristics of public life. In contrast, others understand it is a residual 
category (to only explain what cannot be described by other plans). Thus, there is no single view on the subject. William Mishler and Richard Rose (2001, P. 3062), for example, claim that the recognized antagonism between cultural and institutional theories is generally exaggerated - this seems a good start.

Historians also often criticize American political scientists. The criticisms focused on two fundamental points: for claiming that all societies would have a particular stage to go through until the perfect model; and for saying that there could be a homogeneous national culture autonomous from the global culture. According to Sérgio Bernstein (2009, P. 32), for historiography, political culture is something else, as it finds the existence of several coherent representation systems, however rivaling each other. Furthermore, it is an integral element of collective behaviors, norms, and global values. This article, however, adopts a general view closer to that of Rodrigo Patto Sá Motta, who claims that there is no reason for the opposition between the concept of political culture in the singular (such as national) and that of political cultures in the plural (disputing spaces); because it is possible to understand the concepts as complementary. Furthermore, it may be interesting to understand political culture through comparison, as long as this does not imply "hierarchization." Moreover, Motta finally proposes that political culture should not be reduced to "representations," as practices are also essential to understanding behavior. (MOTTA, 2014)

It is undoubtedly challenging to isolate the role of the political culture in determining human behavior. However, this does not detract from the importance and usefulness of the concept. Nor does it seem relevant to propose a final answer about what matters most in shaping decisions - whether economic or cultural factors. Instead, we assume that economic and ideological differences are rooted in the political culture. ${ }^{2}$ This approach results from a methodological option that seems to be consistent with the rest of the propositions. In this sense, Karina Kuschnir and Leandro Piquet Carneiro (1999, P. 236) confirm that the most mature cultural studies of later generations of Political Science (such as Robert Putnam) already emphasize both the performance of institutions and subjective attitudes.

${ }^{2}$ We are using Roger Chartier's perspective for this (CHARTIER, 1988). 
While empiricists have data and quantitative research as sources, theoretical analysis can promote reflections from social facts, events, public policies, legal norms, cause and effect relationships extracted from the logical verification of reality. Conclusions are obtained from hypotheses resulting from the capacity for subjective understanding about the problem with the help of academic scholarship. We use some operational concepts with greater emphasis, starting with inspiration from typical historiography, law, and political sociology studies. We seek to study the history of the present time by interpreting the current political facts through ontological and ethical motivation. We do not attempt to fill in the gaps but understand the present as a dynamic element as a condition for the existence of the past and the future (CARVALHO, 2018, P. 59).

Understanding authoritarian guidelines reveal how democracies work, which is fundamental to the legitimation and effectiveness of collective participation. ${ }^{3}$ Concerning this point, the article comes close to the approach taken by José Álvaro Moisés (2008), who seeks to combine political culture with the performance evaluation of institutions. The survival of authoritarian social representations compromises the acceptance of the democratic regime, as much as the difficulties of democratic practices can undermine popular confidence in the new system. Furthermore, it seems relevant to consider the structural weaknesses of democracy itself. ${ }^{4}$

Therefore, it is crucial to understand Brazil observing its distrust of democracy and lack of commitment to the rule of law. Historically, Brazil would have the aggravating factor of experiencing, over the past century, two authoritarian experiences of enormous repercussion in the conformation of a social imaginary refractory to democracy. ${ }^{5}$ Both the dictatorship of the so-called "Estado Novo" (1937-1945) and the civil-military dictatorship (1964-1985) implemented or increased patterns of political behavior that contributed to an evident rejection of democratic practices. Even after the re-democratization of

\footnotetext{
3 See NEVITTE, 2014, p. 35-58.

4 That is, from the perspective of Rosemberg (2020).

5 We understand by social imaginary a set of feelings that can be apprehended by analyzing the forms of internalization of the messages generated and issued by the political power and transformed into public opinion, tending to be hegemonic. (ANSART, 2019)
} 
1985, a series of behaviors and moral values consolidated within these regimes spread, reaching Brazilian society until the present moment. Changes have occurred, but these are not enough to eliminate phantasmagorias and their residues, which always reappear (GINZBURG, 2012, P. 221).

The absence of a constitutional culture strongly linked to fundamental rights is an essential feature of the Brazilian reality. ${ }^{6}$ Besides, this local reality is inserted in a global context of a crisis of democratic institutions that have been called "post-democracy." Globalization had a significant impact on social relations in Western democracies from the 1980s onwards, bringing neoliberalism (a current that marks Brazilian history after the 1990s) in its political and economic core.

Considering these premises, the essential question that gives rise to this article is: How can Brazilian civic culture be understood at the end of the second decade of the $21^{\text {st }}$ century? More specifically, how much democracy recognized by the institutions is manifested in reality, particularly in this crisis period?

We hypothesize that Brazil is experiencing a specific early 21st-century crisis. There is a low correspondence between the theoretical model (the ideas and legal system) and what occurs both in the political reality (institutions performance) and in the social practices and representations (culture). This hypothesis is consonant with Berstein's proposition (2009, P. 35) that every political culture comprises an ideal representation. Moreover, between the ideal model and the realities, the gap is evident. It is to bridge this divide that political action arises. However, in the realm of reality, there are also disputes between ideals. At certain times, there are plural political cultures that invoke antagonistic values.

On the other hand, it is necessary to consider that there are "dominant political cultures" resulting from social responses that seem more relevant to the historical moment. They then have more power of attraction, creating a "sociopolitical ecosystem" that gains broad support. As explained by Berstein (2009, P.

\footnotetext{
${ }^{6}$ Contrary to what happens in consolidated democracies, which, even in the face of the crisis phenomenon, manage to overcome difficulties without deviating from fundamental rights. On the subject, see GARCÍA OLIVA, 2019.

We are using the term "post-democracy" as in the work of Céli Pinto (2017).
} 
38), this phenomenon does not arise by chance. He is, in general, the answer to social problems. There is a process of diffuse interiorization resulting from political socialization.

Brazil experienced a process of social modernization between 1994 and 2014, with the strengthening of liberal democracy both in the institutional sphere and in social practices and representations. However, this modernization process has failed to reverse the underground roots of Brazilian civil society, whose authoritarian identity is still solidly established as a social imaginary. For this reason, it is possible to defend the hypothesis that the Brazilian modernization process of this period was ambiguous or incomplete. Liberal democracy and the rule of law in Brazil are fragile institutes and perennially threatened to suffer setbacks.

The period started in 2015 is an example of a setback. A new political trend, inverse to the previous modernization process, begins to dominate the national scene. Conservative groups start to demand institutional reforms and to foster a change in the social imagination - in a manifest disregard for values such as "fundamental rights," "rule of law," and "democracy." The result of this paradigm shift is social setback (with reduction of rights mainly for vulnerable groups) and democracy decay (with the advance of far-right groups in elections). ${ }^{8}$ From the point of view of the social imaginary, ${ }^{9}$ the idea of a progressive and liberal society (which had been developing in the previous period) is replaced by a moralistic and conservative society (which is gaining more and more space). The confrontation between these two aspects causes the country to be sharply divided - the stable and consensual phase, typical of the modernization period, is replaced by a conflictive and unstable phase. Authors like Rafael Valim come to evaluate that the reigning instability can also be determined from the neoliberal domination model imposed since 2016 (returning to a typical discourse of the 1990s), ${ }^{10}$ generating, in turn, a state of exception, by which democratic practice is neutralized (VALIM, 2017, P. 34).

\footnotetext{
8 The concept of "democracy decay" is taken from the work of Tom Daly (2019).

9 The concept of "social imaginary" is controversial. About the subject, it is interesting to see Claudia Strauss (2006).

${ }^{10}$ A discourse well represented by the works then published by Luiz Carlos Bresser Pereira focused
} 
To some extent, this is not just a Brazilian phenomenon. It is certainly possible to identify characteristics of the Brazilian political and social processes shared by more advanced democracies. The idea of universal values and democratic homogeneity brought about by globalization is being challenged globally by returning from identity and localist perspectives. Exceptional measures are not practiced against vulnerable populations only in Brazil, but also in Europe, against illegal immigrants (CALOZ TSCHOPP, 2019), and in the United States, against the black population, which is criminalized and imprisoned with greater intensity in governments neoliberals, which even reinforces their electoral victory. (WACQUANT, 2011) There is a revolt by the subjects who were left behind in the modernization process. The result is skepticism about democracy. In countries like Brazil, this is even more serious due to the precariousness of its modernization process, which is constantly threatened by racist and authoritarian social roots.

In this context, it seems reasonable to argue that Brazil needs improvement in its "social capital" - that is, there is a need for a qualitative increase in the democratic participation of society. However, it is not easy to achieve this improvement, considering the substantial "socio-economic status participation gap" experienced historically by the country and worsened in recent years. The precarious process of social modernization between 1994 and 2014 failed to solve this structural problem. Moreover, now, in a moment of inversion of the modernizing paradigm, the tendency is to expand the setbacks and reverse the advances of liberal democracy, the rule of law, and the welfare state - the typical model of the end of the 20th century that was enshrined in the 1988 Constitution.

Considering this historical context, another question needs to be posed for an adequate analysis of the phenomenon: would the advent of new disruptive technologies have the capacity to impact this situation, improving the quality of democratic participation, and resuming the modernization process? Some authors say yes, but the hypothesis is difficult to confirm, especially in developing countries like Brazil. Moreover, even though it is difficult to give a definitive answer 
to the question, the reflection is valid by itself and helps to understand the other variables.

Furthermore, social modernization also results in negative externalities, such as those arising from the conflict between "losers and winners." Democratic quality requires equal participation. How to guarantee equality among citizens in such an adverse social reality? It is important to note that the modernization process generates even more social demands. These demands can never be fully met, especially in periods of economic crisis. Failure to meet these demands creates frustration, not only with the economy but also with democracy itself. The more democratic society was, the more critical and demanding it would be. In Brazil, it is possible to observe the paradox clearly: the economic development that occurred in the period 1994-2014 made possible the revival of the authoritarian mentality precisely in the current middle class - on the one hand, the most benefited by modernization, on the other, the most frustrated in their (high) expectations. This situation facilitated the advent of intense ideological polarization, demonstrating the fragility of Brazilian democracy and society's social capital. Contrary to what might be supposed, the impact of new technologies on political and social relations was very relevant - enabling the proliferation of fake news, misinformation, far-right groups, and clientelistic parties. ${ }^{11}$

\section{The precarious Brazilian social modernization process}

The process of social modernization experienced by advanced democracies since the 1960s has significantly altered the civic culture (DALTON, 2018, P. 215). There was a transformation of the cultural bases of society. Societies improve people's living conditions by increasing wealth, education, and human development. However, all of this was done at the cost of "marginalization" on the part of society. The reduction in the "working-class" and the increase in the middle class redefined workers' occupational and social imaginary structure. Income inequality and wealth accumulation increased along with economic

\footnotetext{
${ }^{11}$ Stuart Davis and Joe Straubhaar (2020) explains this phenomenon very well.
} 
growth, especially in places that have failed to implement an adequate development process in social reality.

Furthermore, the rise in wages of certain working-class segments led to their transmutation into the bourgeoisie, including their mentality. That made the new generations, children, and grandchildren of this new social group much more demanding about their future. Consequently, there is great social frustration at the end of the $20^{\text {th }}$ century and the beginning of the $21^{\text {st }}$ century, in which neoliberal globalization necessarily promoted a reduction in expectations.

The typical modernization process from the 1960s to the 1980s in advanced democracies was replaced by globalization - a process focused on market freedom. It promoted a new increase in economic and social inequalities both within and between nations. At a global level, it implied a reduction in the legitimacy of governments, suggesting fear and insecurity. (HOBSBAWN, 2007, P. 97-115) As Manuel Castels (2018) explained, the frustration of hopes provokes the erosion of the political system and generates indignation against the system. The globalization of the economy and technological communication networks has limited the nation state's ability to respond to social problems. That makes people retreat to their identity groups, causing two fractures: social and cultural. The result is intolerance, xenophobia, racism, and lack of commitment to representative democracy. One of the great fruits of the neoliberal globalization process is resentment against democracy.

Brazil, on the one hand, was included in this globalization process from the 1990s onwards. However, on the other hand, it ended up having a very peculiar moment. The country did not experience the typical development process of advanced democracies in the second half of the 20th century. Instead, the mid1970s to the late 1980s was one of economic crisis and widespread disillusionment.

The 1988 Constitution, the economic stabilization in 1994, and the advent of a successful leftist government in the 2000s gradually change this picture. Thus, the hope of Brazilians is renewed, and expectations for the establishment of a robust process of development are high. Even living with the prevalence of neoliberal ideology and a conservative pact, Brazil has achieved significant 
advances in terms of social modernization at the beginning of the $21^{\text {st }}$ century. (SINGER, 2012)

Several authors analyze the period from the idea of "ambiguity." It is possible to identify a robust modernization process on the one hand and a significant lack of modernization on the other side. Therefore, it is an ambiguous process. It is common to hear that Brazil is a country of intense contradictions that live in a "democratic pendulum," as says Leonardo Avritzer (2018, P. 285), or in an "inertial democracy," as to reply Marcelo Baquero, Sonia Ranincheski, and Henrique de Castro (2018, P. 88). Despite the peculiarities of every country, Brazil fits the general political context of Latin America, whose characteristics until the beginning of the $21^{\text {st }}$ century are: hierarchical economy (with big companies and weak unions), systemic corruption, empowerment of the president, small institutionalization, and weak civil society (CARLIN, SINGER, AND ZECHMEISTER, 2015, P. 11). On the other hand, the Brazilian reality's peculiarities deviate from the general characteristics and make the country very different from other Latin American societies.

Social modernization - fundamentally composed of a combination of redemocratization, economic growth, and technological development in telecommunication - gave rise to important new resources that spread in Brazilian society. Redemocratization brought with it a period of solid institutional consolidation. As Avritzer (2018) explains, Brazil had regular elections in 1989, 1994, 1998, 2002, 2006, and 2010. This period was the most prolonged in Brazil's history without contesting electoral results. Re-democratization was also driven by the advent of the 1988 Constitution and establishing a democratic project based on recognizing fundamental rights (SALGADO, 2007).

Furthermore, several studies point to a rebirth of Brazilian civil society through important social movements (GOHN, 2007). In turn, economic growth is a relevant factor that impacts social modernization. Initially, there was economic stabilization and control of hyperinflation through the implementation of the "Plano Real" in 1994. (IANONI, 2009) Stability paved the way for what Laura Carvalho (2018a) later called the "little Brazilian miracle" arising from the positive impact of the international economic situation in Brazil (and, in particular, the 
commodity boom). This process resulted in a significant improvement in Brazilian inequality indicators and a great reduction in unemployment. Finally, different instruments of digital inclusion, access to information, and e-government were able to expand with the emergence of new telecommunications infrastructure technologies and, particularly, the internet.

The emergence of the Fourth Industrial Revolution impacts the transition from the $20^{\text {th }}$ century to the $21^{\text {st }}$ century, drastically reshaping institutional and social relations. (KREUZ AND VIANA, 2018) Inspired by Aldous Huxley, Ana Viana and Letícia Kreus (2018) call this moment a "Brave New World," in which disruptive technologies start to influence the behavior of society as a whole categorically. In this context, Brazil has not lagged advanced democracies. Brazil has become one of the freest and connected countries globally, and its community is one of the most integrated on the internet.

Consequently, the number of access points that citizens use to influence politics has increased - by expanding institutional means of participation. It becomes a "lab of democratic experiments," 12 such as public consultations, public hearings, participatory budgeting, and popular councils. The Brazilian people also have become more educated, more cosmopolitan, and politically tolerant than their twentieth-century ancestors have. Finally, the virtual social networks play a central role in Brazil's "social modernization" process, although its effects may be ambiguous, especially when considering the younger audience. (MORAIS; BAQUERO, 2018)

Contrary to what happened in the countries of consolidated democracy, that was an incomplete and precarious process. On the one hand, there was a "conservative pact" in the modernization process that emerged most visibly with the rise of the PT to Executive Power. Even though "Lulism" can be seen as a progressive trend, elements were perceived that shaped the slow and gradualist pace of a modernization that did not advocate a drastic break with the past. This "modernization" would thus be a process whose vector, repeating previous historical processes, would slowly depart from the vertex to the social base. (SINGER, 2012)

\footnotetext{
12 Expression was taken from Mendonça and Lavalle (MENDONÇA, LAVALLE, 2019, P. 245).
} 
On the other hand, it was a phenomenon founded on institutional ideas and actions that perhaps we are not supported by the established political culture - an authoritarian culture with a deficit of a liberal social imaginary (BAQUERO; RANINCHESKI, 2018, P. 90). However, it is difficult to know whether the crisis that began in the 2010s is a conjunctural phenomenon resulting from the instability generated by a "political outbreak" (which, therefore, will pass, possibly implying a more mature resumption of the process) or if the modernization process was dissolved by the archaic mental structures still present in Brazilian society - that have been merely awakened by the conjunctural politicaleconomic crisis and, therefore, will end up having a structural impact. Nevertheless, in theory, we already know that the lack of some specific assumptions can undermine the diffuse support for the democratic system (DALTON, 1998).

Nowadays, it would not be incorrect to say that the majority of Brazilian society imagines itself committed to the four basic principles that can usually be extracted from the definitions of "citizenship": political participation, autonomy, commitment to the social order, and social citizenship. ${ }^{13}$ Research points to conclusions compatible with those traits. Most Brazilians agree with the democratic ideal. In terms of practices and representations, however, the issue is not as simple as described. Mario Fuks, Gabriel Casalecchi, Guilherme Gonçalves, and Flávio David (2016) ask the following question: How democratic are Brazilian democrats? The authors' response is not encouraging. Using data from the LAPOP - Latin American Public Opinion Project, they conclude that although $65.97 \%$ of Brazilians believe that democracy is the best government, 24.7\% would accept power by a military coup for pragmatic reasons (unemployment, economic crisis, or corruption). This ambiguity in the political behavior of Brazilians is also pointed out in the studies of José Álvaro Moisés (2008).

Eneida Desiree Salgado (2021) demonstrates that despite Brazil having elected left-wing governments to the Executive Branch at the beginning of the

\footnotetext{
13 These are the four principles highlighted by Russel Dalton that enable, in general, the definition of citizenship. (DALTON, 2017B, P. 112).
} 
21st century (notably in the Presidency of the Republic), the profile of the Brazilian electorate remained conservative in a global analysis of the elections. Thus, the election of the extreme right in 2018 was not a fluke of fate but a demonstration of the historical permanence of conservatism. It is not the purpose of this article to explain this apparently contradictory electoral phenomenon - which Salgado very well explored. Nevertheless, it is essential to emphasize that the advance of plural post-material values, as well as fundamental minority rights, can be understood as a trigger for a conservative reaction (beyond the economic crisis). In the same sense is the position of Rosana Pinheiro-Machado, for whom "in Brazil, it is impossible to separate the economic crisis from the male crisis" (PINHEIRO-MACHADO, 2019, P. 92), wanting to emphasize that the economic agenda is embedded in a project against the values of modernity - a project that on the one hand is essentially Brazilian, on the other hand, is part of a "global conservative turn."

That does not mean that all voters can be identified with one or another political culture (nor that there is a rigid link to the permanence of the vote over time). There are nuances and disputes at stake - which even implies the normal existence of groups that can identify and vote for left-wing candidates (such as Luís Inácio Lula da Silva) and right-wing candidates (such as Jair Bolsonaro) at the same time. Likewise, the identification of a polarization process does not mean the disappearance of neutral and center groups. Furthermore, according to Instituto Latinobarometro, the right appears with the most significant support in three elections: 2001, 2003, and 2018. Still, the right appears only with 12.1\% and $18.9 \%$ in self-identification by ideological orientation in this period. (SALGADO, 2021, P. 17) However, these timid numbers did not prevent the election of Bolsonaro and the increasingly important presence of the extreme right in the Brazilian national imagination.

An important peculiarity is that among those who stated in the survey that "in some situations, a dictatorship is better than a democracy," 22\% voted for the Workers' Party, and 78\% voted for the elected president. (SALGADO, 2021, P. 18) Therefore, it is not surprising that a part of Bolsonaro's electorate votes for Lula and a part of Lula's electorate votes for Bolsonaro. This factual situation does not 
impact the conclusions obtained from a cultural approach to Brazilian politics, nor does it contradict the identification of an authoritarian and conservative structural profile. That does not mean that political reasons specific to certain groups are absent (as a function of social class or religion, for example) - and that they do not concern cultural factors but rather the institutional performance of democracy. In Brazil, an idea central from liberalism predominates among our corporate elites: the promotion of an order whose pillar is the "private law society," in which the organization's rules are ordered for an objective that stands above interests collectives approved by established legislatures. (DARDOT Y LAVAL, 2016, P. 165)

However, there is a journey towards the objectivity of the State and the supremacy of the public interest as a criterion of the legal regime of Public Administration (GABARDO, 2017). In a general perspective, Brazilians are increasingly more aware of the distinction between that which is public and that which is private. Such a journey may be credited mainly to the 1988 constitution. There was a paradigm shift in the 1930s and 1940s with the break from decentralization and political clientelism. In the 1960s and 1970s, there was another break, namely, with the merely agricultural and economically weak country (SKIDMORE, 1998, P. 153). However, it was only during the 1990s that Brazilians were finally close to understanding the real meaning of living under a democratic rule of law. ${ }^{14}$ Before this, the most significant modernization changes were enabled by authoritarian regimes. It may explain part of the indifference, on the part of the social imagination, concerning democratic values. ${ }^{15}$ Therefore, it is possible to identify a "modernizing outbreak" in the first internship between 1994 and 2004 and another between 2004 and 2014.

Never in the country's history have so many people left poverty and rose socially - significantly increasing the Brazilian middle class. The conquest of the credibility of the electoral system, ${ }^{16}$ the development of a constitutional valorization of fundamental rights beyond an economic bias, ${ }^{17}$ as well as the

\footnotetext{
14 Several authors have explained this moment, among them, Dalmo Dallari (2000, P. 439-487).

15 That, at least, is the opinion of Paulo Sérgio Pinheiro (2001, P. 260-305).

16 Despite there still being some criticism to be considered (SALGADO, 2010).

17 As Daniel Wunder Hachem (2013) explains.
} 
expansion of the citizenry through social movements, ${ }^{18}$ are both the cause and the consequence of Brazil's social modernization process. The economic development and the institutional strengthening of Brazil by the 1990s until the 2010s fostered a paradigm shift in law, economy, and politics, suggesting the beginning of constructing a social imaginary opposed to authoritarianism (DALLARI, 2000).

The commissions of truth and memory (aimed at investigating the crimes of the previous authoritarian regime) and the spreading of discourses in favor of human rights are examples of this new era that had been announced (SANTOS; BUCCI, 2015, P. 301-326). It is also essential to highlight the expansion of access to education, especially in higher education. LAPOP research shows that higher schooling, as a rule, tends to increase the degree of tolerance of Brazilians - a vital factor for the valorization of democracy (PEIXOTO; SOUZA, 2019). Therefore, the expected trend for the third decade of this century would be to increase the social imaginary of democracy and the rule of law. However, that is not what happened.

\section{The current Brazilian authoritarian setback}

In 2015, it became possible to perceive that trends that were considered unimportant until then become hegemonic, emerging in opposition to the modernizing social imaginary predominant in the previous period. Led by the economic elite, by the media, and by an essential part of the Judicial branch, conservative groups gained ground and offered a new political view. ${ }^{19}$ They projected a supposedly innovative idea that the typical State of the 1988 constitution (a necessarily social and the democratic rule of law state) was no longer good enough. They claimed a need to reform it all. Moreover, the curious

\footnotetext{
18 Regarding the subject, see SILVA, 2015.

19 In other parts of the world, the Judiciary generally acts as a guarantor of institutions, the democratic system, and the Constitution. Yaniv Roznai and Tamar H. Brandes believe in the importance of the Judiciary's action against phenomena such as "constitutional populism" going so far as to suggest a new and more powerful judicial review. (ROZNAI; BRANDES, 2020) In Brazil, however, the reality is more complex. The erosion process experienced by the rule of law and democracy occurred with strong consent and participation by magistrates and prosecutors. As well as the legislators and governors, the judges also want to be the spokespersons for the "people's will." What to do, then, when populism comes from the Judiciary?
} 
thing is that the emergence of a "new right" at this time of transition from the 20th to the 21st century, from a representative point of view, did not occur at the wealthiest level of society. It allows itself to be sheltered in physiological parties, with little numerical representation, and with little or no discipline on its platform. In an article dedicated to the topic, Codato (2006) identifies three main occupations for this group: small and medium-sized entrepreneurs with diffuse specializations, religious leaders, and communicators. Once elected, they begin to bargain for their support with the government itself or with the larger parties, if not with more expressive political groups. Unlike the traditional right, they have fewer ties with the bases that elected them. The conservative view of these new groups (to some extent present since the 1990s) gained strong prominence from the second decade of the 21st century.

This new reality facilitates the advent of government actions with a robust neoliberal character in the institutional field. In other words, they have a political proposal for implementing a Subsidiary State. Therefore, this view contradicts the interventional model of welfare under the terms established by the 1988 Constitution. (GABARDO, 2019) Furthermore, from a moral point of view, it portrays a conservative mentality. (OLIVEIRA, 1995, P. 27) It is essential to consider that even in previous moments, neoliberalism as a force-idea was present (to a greater or lesser degree). In turn, the neoliberal and recessive agenda was current at different times in Brazilian history - even in the first term of Dilma Rousseff. However, the government's turn at this time does not reflect a real mental or ideological alignment but a pragmatic and topical attitude - which can hardly be considered beyond the exclusively institutional space of analysis. Furthermore, they were policies that can be portrayed much more as "government measures" than "state reforms." According to André Singer (2018, P. 197), the president herself imagined that this inversion in her economic policy would only last a year.

On the other hand, it would be quick to agree with Singer that there would have been an effective impact on popular mentality due to these measures. It is a hypothesis. However, it would also be plausible to imagine the opposite hypothesis: that the discrediting of the government, and the negative imagery created around the left since then, came precisely because of the failure of the 
measures. There is a set of factors that go beyond institutional actions and tend to impact political motivation. The election of a progressive and left-wing government was a conjunctural factor within a conservative structure. With this government's economic and moral deterioration, it is natural that forces based on the mentality that opposes it resurfaces, bringing with it all its imagination.

Neoliberal public policies that were previously feared in the dominant political discourse (by unpopular ones, such as privatization) are now accepted with great tranquility by the population (whose focus of indignation was transferred to post-material problems such as fighting corruption and the customs agenda). A demonstration of this situation is the inaugural speech of Michel Temer (2016), who bluntly assumes its religious foundation. Temer is supported by the PMDB government plan entitled "A bridge to the future" - an economic plan that goes beyond orthodox, advocates structural reforms about labor laws, public services (especially health and education), and social security (CARVALHO, 2018A, P.111); a project, therefore, of ostensible destruction of the Welfare State. Only then can a paradigm shift of an institutional character be observed, becoming consonant with the economically liberal and morally authoritarian mentality then on the rise - a different picture from the period before it.

In this situation, there is a need for flexible guarantees and rights to correct institutions, fighting the corrupt, decanting the State, and moralizing life itself. As Ricardo F. de Mendonça and Adrian G. Lavalle (2018) describe, ultraliberal and farright associations start to use a "new politics" rhetoric against corruption (as if corruption were a typical addiction only of State interventionism). However, what they aim at is just a bargain of interests - which ends up being carried out in the name of governance.

This "New Policy" was not enunciated as neoliberalism. On the contrary, simplistic reasoning was presented to society, which affirms the need to end corruption. Without the embezzlement of money, it would be possible to make the State more efficient in its public policies (such as building schools and hospitals). The social imaginary started to link abortion, the LGBT public, and the corruption of customs to the communist danger, a danger that, in turn, was 
associated with the parties identified with the social state model of the 1988 Constitution. In particular, the religious campaign, originating in the United States, pro-life (against abortion) and pro-family (against same-sex marriage), seduced the poor, both Catholic and Evangelical, resulting in local, state, and national electoral defeats.

It should be noted that the advancement of the far-right wing is a political process that expands globally and branches out into institutions that formerly acted as a democratic safeguard. It is a process of such complexity that it is far from being sufficiently understood. In this perspective, we must understand the advance of the right in the world outside the conventional patterns of electoral demand that stimulated party alignments based solely on loyalty to a program. In the last decade, the contagion effect of the right owed much to the extensive use of the opportunities offered by digital mass culture (arising from the significant advance of new communication technologies). When these exist, these easily circumvent legal frameworks by breaking the traditional institutionality of politics, establishing which Pippa Norris defined as the "resentment policy." Through a common-sense narrative, resentment would express the negative protest against a particular progressive, more equal and plural status quo. Therefore, this resentment is an indicator of disenchantment with democratic politics (NORRIS, 2009, P. 193). It is a resentment that finds capillarity in different social strata. One of the strengths of the category of political culture is precisely recognizing that political motivation can occur less due to social positions or agreement with ideas and more due to identification with values, sensations, and traditions. (MOTTA, 2014, P. 27)

Widespread by neo-Pentecostal fundamentalists and ultra-conservative Catholics, a dangerous political moralism starts reaching the understanding of the law, intensifying the process of institutional instability (GABARDO, 2017). According to President Michel Temer's (2016) opening speech, an "efficient democracy" needed to be developed to surpass "liberal democracy" and "social democracy." It would be an "efficient democracy" based on the market from an economic point of view and focused on civil society from a moral point of view. The president called up civil society to return to religious values to conduct the 
republic. However, a society that refuses to see that which does not interest them is driven by the media's factoids (beyond fake news) and by religious and authoritarian groups. Once again, these things occur in moments of intensification of "exception situations" (institutional actions contrary to the rule of law, but which are maintained as valid within the system), manipulation of fear, and the instigation of moralist hysteria (RABELO FILHO, 2013). An "imaginary of Evil" generates social consent for the abandonment of the principles of the rule of law and fundamental rights that are the pillar of modernity.

For instance, a long-term process had strived toward the normalization of sexual and gender differences. However, after 2016, the Brazilian government has adopted positions opposed to the civilizational postulates of modernity. As a result, new acts of violence start to harm vulnerable groups. These groups are submitted to attacks of moral despots and esoteric fanatics inside and outside of the state institutions (BREPOHL, GONÇALVES, AND GABARDO, 2018). Using communitarian pretexts inherent to fear of war and God, the killing of the enemy becomes official public policy. ${ }^{20}$ Thus, our "reserves of solidarity" seem to be exhausted because we are immersed in a "progressive type of regressive modernization" that also covers the shock suffered in the self-image of Western societies. As Oliver Nachtwey (2019, P. 215) suggested, in the public and political spheres, in addition to blatant hatred, dangerous feelings, fantasies of violence, and even death, wishes are spoken lightly.

Witches must exist for someone to be thrown into the pyre while the rest rejoice and strengthen their bonds of group belonging. In the extreme, this is a process of "necropolitics," a process in which human beings are reified with their physical and moral annihilation. As Achille Mbembe (2018) posits, "the last expression of sovereignty resides amply in the power and capability to decide who may live and who must die." Jair Bolsonaro's fight against lockdown measures in the Covid-19 outbreak is the most recent example. Moreover, he has a significant group of followers who do not care about the disease or even the deaths. They are the same people who, over the past few years, have become

\footnotetext{
20 The most striking example of this necropolitical reality is the management of Wilson Witzel, elected Governor of Rio de Janeiro, in 2018. On the subject, see VIANNA, 2019
} 
fanatics for punishing the corrupt (even against the due legal process) and for the selective purification of the system through the strengthening of prison measures. Alternatively, defending the death of their enemies - generally poor, black, gay, feminist, and leftist.

The proposals substitute a post-modern moral state for the rule of law that is convenient to a specific percentage of society identified with the dominating elites and the bureaucratic state casts (in addition to religious fundamentalists). However, in the midterm, it tends to erode the possibility of the economic and ethical development of the country. It is interesting how the punitive illusion contaminates, like a fever, the mentalities of resentful people people who end up legitimizing false moral practices that, in the end, act like a boomerang against themselves. Consequently, no matter who is guilty in the eyes of the Judiciary or the media, the unfavored tend to be the same, even if the crisis extends itself to social groups with better income levels (LONDOÑO, ANDREONI AND CASADO, 2020).

It is not news that there is a low correspondence between the ideal constitutional model established in 1988 and institutional actions or even social practices and representations. However, how this phenomenon manifests itself in different historical periods is peculiar. Brazil went through an unprecedented period of social modernization between 1994 and 2014 - which suggested the beginning of a structural paradigm shift. However, the rapid setback seen in the subsequent period puts the optimistic analysis of the phenomenon in check. Knowing to what extent this is a conjuncture phenomenon, as well as what its consequences will be, is very difficult - as challenging as making the "history of the present." ${ }^{21}$ That does not prevent the moment from being critically analyzed.

In this second decade of the 20th century, the Brazilian politicalgovernmental crisis is a reflection, more than a cause, of the absence of a civic culture that haunts Brazilian civil society for most of its history. To a certain extent, this phenomenon reflects an incomplete social modernization process, which makes democracy very susceptible to inclement weather typical of

\footnotetext{
${ }^{21}$ In this sense, the analysis carried out by the history of the Present journal is adopted. See THE EDITORS, 2011, p. 1-4.
} 
economic or institutional crises. In general, Brazilians claim to have an appreciation for democracy. However, using data from the Latin American Public Opinion Project - LAPOP, Mario Fuks, Gabriel Casalecchi, Guilherme Gonçalves, and Flávio David (2016) affirm the need for a cautious view regarding our adherence to democracy. A problem with new democracies is that the people see it as a solution to all issues not solved by the previous regime. This emphasis on performance, in turn, reflects the lack of attachment to democracy as a matter of principle. On the other hand, this situation generates great frustration (or hatred) when the system does not fulfill its promises. Of course, that can happen in consolidated democracies (such as the United States of America), but it is even more impactful in young democracies like Brazil.

To a certain extent, this phenomenon matches what has been happening in advanced democracies due to globalization. Cultural aspects of the modernization process tend to discredit community values. Modern individualistic universalism has broken with order, stability, and tradition, making people think they are losing their place in the world (DALTON, 2018, P. 219). From historiography, Raoul Girardet (1987, P. 103) discusses "the myth of the time before": people, in times of insecurity, tend to seek refuge in what their memory presents as a better situation. "The dream that once was better" comes up. With its retrospective function, supported by a naive nostalgia, this myth has an illusional role, sometimes very dangerous. Specifically, in the case of the crisis of democracy, this phenomenon is verifiable. Democracy is described as an obstacle to happiness (so present in the past). If so, the doors are opened for undemocratic regimes. In the same sense, Julien Gest, Reny Tyler, and Jeremy Mayer (2017) developed the concept of "syndrome of nostalgic deprivation," resulting from the perception of loss in social status when traditional values are replaced. According to "Deprivation Theory," reactive attitudes are driven by deprivation, especially when the individual makes comparisons between his present and his past or his situation with other groups or classes. Therefore, it is not a matter of greed or desire but a grievance against the world in which we live (JAKOBSEN, LISTHAUG, 2014, P. 213-239). In Brazil, making the same analysis, Rosana Pinheiro-Machado highlights the two feelings of anti-globalization 
conservatism: the "sense of lost privilege" and the "sense of victimization" of men who feel humiliated and dishonored. His hatred of the advances of modernization is an "act of faith" that there will be a return to his happy lost past. (PINHEIROMACHADO, 2019, P. 93)

No wonder expressions of support around the dictatorial regime have been frequent in the last years. On the other hand, this phenomenon is not only national. The return of right-wing populism and exacerbated nationalism and neo-fascist political thought are real geopolitical dangers, as Alain Touraine (1997, P. 12) already denounced in the late 1990s. This danger can have negative consequences of social modernization - but its effects are different in each situation. In advanced democracies, Russell Dalton (1998) says that citizens are also less confident in democratic institutions. However, this skepticism has not significantly affected support for the principles of democracy. That is, there is a demand for improvement in the system. Contrary, in Latin America, particularly in Brazil, pessimism can indicate a severe factor of formal destabilization of the rule of law (doing open windows of opportunity for authoritarian setbacks). (AVRITZER, 2018, P. 275)

\section{The democratic participation gap in the politics}

The mental representations of any given society do not always follow the same direction of legislation or those ideas present in the academy. The second decade of the $21^{\text {st }}$ century confirms this proposition for Brazilian history. Not only is a lack of harmony common, but also an abyss between the predominant ideas in the academy and those who compose the social imaginary. Such dissociation may also be produced by a weak structural link between the practices and the views - particularly between what one thinks and what one does. So, in this context, to claim that we need an improvement in the "social capital" (democratic quality) of Brazilians is a defensible hypothesis. The first step in this direction, perhaps, is to promote the quality of political participation.

Mitchell Seligson and John Booth (1976), however, have a different thesis. First, the authors challenge the image that citizen participation in Latin America is minimal. From a survey in Costa Rica, the authors assert that the participation 
numbers are very similar to those of developed nations. Second, they challenge the claim that civic activism should be encouraged, as mass mobilization can lead to political instability or poor resource allocation. Their arguments, however, are not very convincing and are not liable to disconfirm the vast literature on the subject. Not only from sample interviews but also through different sources of research, there is extensive literature that shows both the limitations of participation in Latin America and Brazil. There is also literature that demonstrates the importance and benefits of civic activism. The authors' argument has an authoritarian connotation. After all, nothing seems to be more democratic than the mobilization of the masses and the struggle for resources.

Actually, the problem seems to be the opposite. Although there are many protests and social movements of political reaction in the history of Brazil, which can be well demonstrated by the strength of the protests in 2013, ${ }^{22}$ these episodes do not portray the mentality that structures civil society over time. If considered every day, the cultural norm in Brazil is political apathy and the absence of public transparency and autonomy of private action. To some extent, these characteristics combine with what Rodrigo Patto Sá Motta (2014, P. 30) calls a "conciliatory tradition": a weak political performance by Brazilians permeated by "occasional participatory peaks" that are intense but fleeting. This tradition has positive points (such as less political violence, less hatred, and minor trauma) and negative points (such as the historical permanence of problems that tend never to be resolved).

In addition, public authorities are always at risk, given both the fragility of the rule of law and the difficulty of government officials securing legitimacy. The Brazilians are generally used to political instability, coups $d$ 'état and the replacement of rulers outside the game rules. Laws always seem to be subject to revisions according to the convenience of the occasion. Moreover, finally,

\footnotetext{
22 "The year 2013 was a turning point in Brazilian politics. A huge cycle of protests filled the streets of hundreds of cities and towns throughout the country, expressing many (often contradictory) grievances and criticisms. Like what had recently happened in contexts as different as Spain, Turkey and Egypt, hundreds of thousands of Brazilians were engaged in street demonstrations, occupations, and activities on social media. As in similar experiences worldwide, such activity was chaotic in the sense that it could not be easily comprehended." (MENDONÇA; BUSTAMANTE, 2020)
} 
Brazilian citizens do not feel responsible for each other. They believe that the State is there for that. The civic ethics of well-being (happiness) cannot overcome the hedonistic individualism rooted in its political culture. With the "individualization of politics," decisions are not derived from group identity but are made from items such as personal preferences, performance judgments, and the image of the candidates. It is a Latin American trend that seems to be even more prominent in Brazil. Precisely with the conciliatory tradition (which implies a game of mutual concessions), "personalism" is a commonly recognized characteristic of political culture. The authors, such as Motta (2018, P. 115), highlight the importance of personal ties, kinship, friendship, sponsorship, and low adherence to universal projects and impersonal institutions. The identification with people and not projects, in turn, explains the valorization of charismatic leaders in politics.

One of the most significant political problems of contemporary Brazilian society and the State is dealing with issues that transcend specific interests. The mobilization of labor unions is decreasing in Brazil and the activity of most other traditional groups. The interesting thing, however, is that has been no decrease in the activities of religious groups. Notably, neo-Pentecostal groups have gained strength, both in civil society and within public institutions - electing representatives for legislative and executive branches and occupying important judicial positions. Apparently, religious activities are one of the only forms of "social interaction" that are increasing. The problem is that it is a group that promotes a political vision that goes back to the beginning of the last century, of neo-Calvinist character, re-editing the model of free enterprise for the most impoverished populations, based on the denial of State interference. (ALENCAR, 2018)

Thus, we disagree with Taylor Boas and Amy Smith's (2015, P. 99-121) conclusion regarding the positive character of the growing role of religion in Brazilian politics. The authors argue that incorporating a diverse set of interests in the electoral process would be essential to legitimize the regime. The conclusion, however, is simplistic and goes beyond the research premises. First, the intensity in which evangelicals participate in politics gives them a 
disproportionate influence. Second, they tend to vote according to the hierarchical indication of their leaders (both reasons are demonstrated in their research). This phenomenon has nothing to do with substantial democracy. In practice, considering the other variables, the result has been developing an increasingly anti-democratic mentality in Brazil - very distant from building a public interest that can be minimally shared from the premises of the social modernization process. As Joanildo Burity (2018, P. 15) clarifies, a different form of neo-Pentecostal manifestation prevails from 2014 onwards: the typical conservatism of religion is transformed into solid fundamentalism - opening the way for the emergence of a sectarian mentality that is contrary to political participation, but whose objective is the conquest of institutional power. On the other hand, the difficulty in adhering to universal projects (one of the pillars of the modern mentality) is also manifested through the process of social division. Nowadays, citizens are fragmented in their different cultural and economic interests in a very intense way.

As Dalton (2000, P. 925) said on the subject, citizen sophistication, interest, and participation in politics have generally been increasing in affluent democracies. That empowers the public overall. However, the increase has come disproportionately among the upper strata of society, the better educated, and the middle/high class. That leaves the less educated and working-class behind, without viable social institutions to mobilize and represent their interests. In developing countries, the author's claim seems not only valid but even more prominently. Often protests and struggles grow in a process of social modernization not because of dissatisfaction with the government, but because the development process, by itself, provides resources for those with political demands (JAKOBSEN, LISTHAUG, 2014, P. 216). However, if funds are unevenly distributed, this is a problem for democracy. Some groups will be at an advantage because of their higher fighting capacity - which is a typical phenomenon of neoliberal globalization (whose principle is the survival of the strongest).

In this context, Brazil experiences a "socio-economic status participation gap" - a difference in resources for the exercise of citizenship. ${ }^{23}$ However, this

\footnotetext{
${ }^{23}$ The expression in parentheses is inspired by the work of Russell Dalton (2017B, P. 210).
} 
pattern may be a global problem, considering that research shows that the politically rich are getting richer and the politically poor are getting poorer, even in advanced democracies. In countries with an unstable democracy, the problem occurs more intensely and seriously. As Brazil is one of the most unequal countries globally, with insufficient civic levels, the result is predictable. In particular, informational biases are resulting from cuts by race, gender, and income. In other words, "the groups that have reduced access to information are the same groups that have historically been excluded from access to several other resources in Brazil." (RENNÓ, 2007, p. 742)

It is essential to consider that, in practice, the process of redemocratization and social modernization that took place before 2015 did not automatically convert into very significant growth in participation. The participation and social mobilization rates of Brazilians remain among the lowest in Latin America. It is essential to understand that development is not restricted to increasing income; rather, it concerns the feeling of well-being and happiness. As Inglehart (2009) states, "living in an environment of economic and psychological security seems to have a powerful impact on a society's happiness level."

Insecurity, portrayed by the fact of adequate protection against subsistence risks, generates disengagement. Sarah Brooks proves that the lack of access to social protection mechanisms reduces qualified civic participation. Vulnerability prevents people from spending their time on activities that require immediate effort and uncertain or long-term benefits. Moreover, the most interesting thing about this process is that not only the poorest are left out of active citizenship. The newly formed Brazilian middle class also fears losing what little they have achieved. Their fear of victimization for violent crimes is an element that erodes the sense of community and group solidarity. The growth of labor market informality left approximately 43\% of ex-employees uncovered from a security system (BROOKS, 2014). In addition to poverty itself, Brazilians live a scenario of insecurity and risk. A script that is exhaustively projected by the media, making this reality build a social imaginary that erodes loyalty to democracy. As Eduardo Salinas and John Booth (2014) demonstrate, the personal 
experience of victimization is not as relevant as the general perception of the problem. Orlando Pérez (2015, P. 323 ET SEQ.) had the same conclusion.

Unfortunately, the Covid-19 coronavirus crisis tends to increase the level of fear and unpredictability. Therefore, the role of civil society tends to be weakened, which, even when the crisis is overcome, will intensify its social isolation, further increasing the relevance of internet means of social integration. That was occurring at a rapid pace, regardless of the Covid-19. A new civic culture, now virtual, is being born based on the latest disruptive technologies that drive the social process. Hence, the big question is: will the socio-economic status participation gap be reduced in this new environment? Apparently not - all evidence is contrary. However, it is not yet possible to make long-term analyzes regarding the influence of technology and the internet on the political behavior of citizens. Furthermore, studies have already been carried out point in opposite directions. For example, some reviews ask whether the shift from the "in-person" association to a virtual association will harm democracy. Some authors say yes; others say no.

Naturally, the first problem that comes to mind is the income inequality of Brazilians, which impacts their capacity for virtual interaction. A significant percentage of Brazilians do not have adequate broadband, not even computers or devices necessary for efficient access to the internet (ARAUJO, 2019). There is undeniable difficulty in accessing digital devices by Brazilian citizens. IBGE data shows that the percentage of households that used the internet rose from 69.3\% to $74.9 \%$ from 2016 to 2017, representing an increase of 5.6 percentage points. On the other hand, 17.7 million households are still disconnected (AGÊNCIA DE NOTÍCIAS, 2018). According to a survey carried out by the Economist Intelligence, Brazil occupies $18^{\text {th }}$ position in a ranking of 75 countries regarding the conditions of access to the internet (DTCOM, 2017). United Nations (2017) survey in 2016 shows that Brazil ranks $44^{\text {th }}$ in terms of countries providing typical electronic government services. These results show that the Brazilian government needs expanding investments in broadband to enable real access by citizens to the digital world. Digital inequality is a new problem for developing countries. It urgently needs to be solved by creating inclusion policies - what is possible, at 
least for rich countries like Brazil, where the problem is not the gross domestic product but the inequality of distribution of the collected resources.

Therefore, even considering the problem of digital inequality, new forms of interaction (networking, chat rooms, online multiplayer games, blogs) are technologies that have the potential to expand social interactions. More than that, such communications can develop social capital (ANDUIZA, JENSEN, AND JORBA, 2012). Contrary to Robert Putnam's (2010) pessimism, Ricardo F. de Mendonça and Ernesto Amaral (2016) deny that online forums are inhospitable places for democratic deliberation. In other words, part of the specialized literature states that it is possible to develop more civic culture through the internet. There could be the development of a higher "critical analysis" based on the collection and exchange of information and increasing the time for reflection, which would allow a better assessment of different points of view. Several studies point out that internet use is associated with higher levels of political participation. The use of Facebook, for example, would have the ability to facilitate previous and new faceto-face interactions, improving civil engagement, social trust, and the overall level of satisfaction with life. If so, such a virtual interaction would be able to fill the vacuum left by the decline of the "traditional social group membership" - at least among young people (DALTON, KITTELSON, 2012). This new type of participation is generally a positive objective of democracies and generates more control over political activity, increasing the pressure on the elites.

However, these conclusions must be applied with caution in countries of unconsolidated democracies. At least in Brazil, the proposition needs to be analyzed from different angles. That also does not imply agreement with the thesis that social engagement tends to decrease with social modernization - a "bowling alone" (PUTNAM, SANDER, 2010). In fact, Brazil is experiencing a series of paradoxes. Part of society is inert, generally located at the center, and avoiding any political participation. That is an exercise in the lack of otherness and hedonistic individualism (typical of the technological consumer society). On the other hand, another part of the community has become very active, composing cadres of the extreme right and militant left. Despite being a minority, these 
active groups guide the political debate influencing moderates - mainly on the internet. ${ }^{24}$

This phenomenon ends up increasing extremist polarization. From a formal point of view, this is a weakness of democracy, whose freedom and plurality can foster anti-democratic radicalization. That is why it is so important to break with the material legacy of authoritarian culture. Sufficiently stable democracies can deal with their weaknesses. The tricky thing is to know how healthy Brazilian democracy is to survive this moment of crisis.

\section{The citizens between civic culture and democratic performance}

Social modernization also results in negative externalities. The social modernization process creates new economic conflicts between winners and losers. Winners are not concerned about losers. More than that, they end up firmly embedded in beliefs that concern their own interests, such as the acceptance of inequality as an inherent element of progress or an almost religious belief in meritocracy. The more socially modern a democracy is, the more diverse it will be in terms of culture, generating demands for new social norms with potential redistributive effects. This process tends to produce a reaction that creates new tensions between "equality of opportunity" and "equality of outcomes." This whole phenomenon is permeated by a cultural tension between "modernization" and "conservatism" (DALTON, 2018, P. 218). If this is already observable in advanced democracies, what about immature democracies?

One of the basic principles of democracy is equality between citizens (DAHL, SHAPIRO, 2015). In general, political participation requires resources in the hands of the upper strata of society (VERBA, SCHOLOZMAN, AND BRADY, 1995). Sidney Verba seems to be right in asking whether these changes in political participation (and social modernization itself) generate inequalities. After all, qualified citizen participation requires skills and conditions not present in the entire social body. In immature democracies like Brazil, the problem is even more

${ }^{24}$ Mainly for its ability to influence the independent public (INGHAM, LEVIN, 2017). 
severe. One of the most critical assumptions for analyzing the construction of the imaginary of the Rule of Law and democracy in Brazil is the acceptance of inequality as a structural feature. Brazil's political culture is characterized not only by social inequality but also by the "political inequality" inherent to it. There is a historic combination of social inequality and democratic deficit (BAQUERO, RANINCHESKI, 2018, P. 91). Economic development generates capacities, aspirations for freedom generate post-material demands, and democracy generates opportunities. People with economic and cognitive limitations are less concerned with political participation, as capacities define the parameters for effective demands. Therefore, economic development, civic culture, and democracy are linked in a single "syndrome" of social reality, as described by Christian Welzel and Ronald Inglehart (2001, P. 23).

The consequence of this process is the increase in the level of demand from different audiences. Aspirations increase because democracy, paradoxically, encourages criticism about democratic institutions. Emancipatory values transform desires for democracy. Welzel and Alexandro Alvarez (2014, P. 53) called this emancipatory transformation an "enlightenment effect." The more liberal the understanding of democracy, the more critical society will be. Moreover, "its enlightenment effect unfolds independent of whether society has a long, short, or no democratic tradition." The greatest strength of democracy is, at the same time, its greatest weakness. The existence of emancipatory values and a more robust civic culture is a good reason why people evaluate institutions critically.

Analyzing the Brazilian case, Maria Alice Rezende de Carvalho (2002) concludes that it is important not to exhaust the analysis of democracy in considering the organization and functioning of institutions. Instead, it is necessary to analyze the complex relationship between political culture, social capital, and the issue of the democratic deficit. The challenge proposed by the author for contemporary democratic theory is to deal with this problem without succumbing to instrumental rationality in an environment of solid cultural pluralism. There is a long and crucial theoretical discussion on the subject.

Edward Muller and Mitchell Seligson (1994) claim that most attitudes of civic culture have no impact on changes in democracy. On the contrary, perhaps 
democracy affects civic culture. Political values would be affected by the performance of the democratic regime. In other words, the instability of democratic regimes is much more due to other factors, such as economic inequality. In fact, both studies from Welzel and Inglehart or Müller and Seligson have relevant empirical data to support their propositions, which, however, are contradictory. Lucio Rennó (2011) suggests that perhaps the problem is measuring social capital, but we do not believe that would end the controversy. In the Brazilian case, it would not be difficult to defend the paradoxical hypothesis that it was precisely economic development that contributed to the outbreak of authoritarian thinking in the middle class and upper strata in the last years.

However, from the consulted literature, it is possible to say that the interpretation given by authors like Almond and Verba, Seymour Lipset, Putnam, and Inglehart seems more appropriate. The latter, in fact, has a not-so-rigid understanding of the phenomenon. As Eduardo Salinas and John Booth (2011) explain, Inglehart understands that there is a reciprocal relationship of influence. Social capital contributes to sustaining democratic attitudes, and, in turn, living in a democracy probably has pro-democratic socializing effects. Reflecting on the subject from political theory and history, in addition to the surveys, the criticism of Müller and Seligson does not convince, at least in the Brazilian case.

A democratic political system requires a diffuse reserve of support regardless of the immediate results of public policies so that the regime can register periods of dissatisfaction. That does not mean forgetting that there are endogenous weaknesses in the "immune system" of democracy. As Shawn Rosemberg explains, citizens find it difficult to meet the requirements and demands of liberal democracy. They see its practices and representations as incomprehensible, strange, and challenging to achieve. For a portion of the population, authoritarian populism offers a social imaginary that is more easily understood, engaged, and enforceable. Self-direction democracy requires not only cognitive ability but also emotional capacity, that is, a sense of security plus self-confidence (ROSEMBERG, 2020). There is, therefore, no single causal relationship. Ideas, practices and representations, political culture and institutions, structural and conjunctural factors - all are elements that influence political behavior and, in short, history itself. 
Any discussion regarding the citizen's political behavior is based on assumptions about his decision-making skills: their level of knowledge, the ability to understand, and their interest. It seems reasonable to assume, then, that political awareness is fundamental. Democracy depends on citizens choosing parties that share their political values. That leads to the existence of an adequate representative system. If we analyze the real experiences of the past, we will see that no political regime has achieved better results than the welfare state - as confirmed by authors such as Dalton (2017A). In other words, we continue to need a regime that, in addition to the institutional strengthening of liberal democracy, can create a personal and social security system for the population. It will not be possible to bridge the democratic gap without reducing social inequalities and improving conditions for the participation of vulnerable groups - ensuring security and self-confidence for all different groups and social strata.

However, this is only a necessary condition, not enough condition, for an optimal representative system since the content of the represented political values is of significant importance. When democratization only affects the institutional system without changes in socialization, they tend to be more unstable and illegitimate. (KUSCHNIR AND CARNEIRO, 1999, P. 234) Democracy is impaired when a distinguished group of society starts to think and act in the opposite direction: not caring about maintaining the rule of law, doubting and disrespecting institutions, and asking for the end of democracy and installing a dictatorship. Alternatively, else seeking to reconcile the meaning of democracy with non-democratic values. Knowing an appropriate view of democracy is essential, especially in societies where populist and authoritarian leaders misuse the term to benefit their self-interests. What matters for the democratic regime is not the mere desire for democracy in the abstract but the "spirit" in which this desire is inserted (WELZEL, ALVAREZ, 2014). Today's Brazil is a clear example of the misuse of the term "democracy" by groups that are evidently populist or authoritarian - such as those who call for "constitutional military intervention" (which is an obvious contradiction in terms).

Moreover, this becomes even more dangerous if the action takes place in the internet environment, with an infinite capacity for the proliferation of fake 
news and misleading information. Disinformation poses substantial dangers to democratic debate. That is already happening in some countries, emphasizing Brazil and in situations of severe institutional crisis and social risk. Currently, the tenuous stability of forces that prevailed in the traditional media environment has given way to an imbalanced relationship. Fake news is driven by factors such as the decentralization of the means of expression, the reduction of market entry barriers, the personalization of advertisements, and the rise of new intermediaries. (CARVALHO, 2020) On the other hand, clustering based on sectarian interests is enhanced by misinformation, generating a political environment of intolerance and hatred. It is alarming to see that, in more recent research, the most educated social strata now appear to be the least tolerant contradicting the thesis commonly accepted by specialized literature - in addition to denying the country's trend (RIBEIRO, FUKS, 2019).

People have ideological preferences about information-based public policies. Without information or with incomplete, false, or misleading information (as in the case of fake news), there is a severe compromise of the choices made by the people. In this context of precarious information, political results (notably electoral) become an expression of opinions or group loyalties instead of actions typical of republican citizenship. More than that, the expansion of the media can increase the ideological polarization towards extremism, considering that people tend to look for information to confirm their points of view and seek support in groups that share the same ideas (LEVENDUSKY, 2013). This phenomenon tends to unite groups that share the same postulates of interpretation of life. They do not need to be of the same generation nor the same social class. Even though they are very different people, they start to participate in a "communion that creates solidarities" (BERSTEIN, 2009, P. 43) of an emotional nature that reaches the vote in the final analysis.

Thus, a vicious cycle is promoted that can be aggravated due to the absence of "political mediation" through representative institutions. Direct and unmediated contact between politicians and citizens expands the possibilities of fostering political demagogy and extremism. However, this is precisely what happened when humans entered the Age of Facebook, WhatsApp, Twitter, and Instagram - preventing the enlightenment effect of democracy. 
There is, therefore, an indeterminate field in the analysis of political action in the considered historical period. Motta (2018, P. 133) portrays this indeterminacy well. The precariousness of political democracy as a cultural trait contributes to the difficulty of transforming the permanent social situation of inequality. On the other hand, the author proposes that it is precisely at critical moments that new configurations and ruptures can emerge. Political cultures can change. One hypothesis is that this is happening in Brazil. There are noticeable changes in political participation (for better or worse), even though the social gap remains wide. Nor should we ignore the hypothesis that the exacerbated polarization may demonstrate the inevitable exhaustion of the conciliatory tradition. On the other hand, it is undeniable to recognize old patterns such as personalism and distrust in institutions, which suggests that politicization operates at a superficial level or only refers to antagonistic and ostensible minority groups. It is neither possible nor convenient to end these questions that concern both civic culture and democratic performance alike.

\section{Conclusion}

As Bernstein (2009, P. 41) explains, the historiographical aim of studying political cultures is to answer the problem of the motivations of political activity. These motivations need to be described as a complex and evolving phenomenon. Yet, the recognition that citizens' behavior is established by long-term processes, as is the case with the political culture, does not prevent the acceptance of conjunctural factors of impact on people's decisions. For instance, the current technological reality favors the decline of long-term influences and the expansion of short-term influences. Indeed, "public opinion" is becoming more fluid and unpredictable (DALTON, 2000, P. 924). However, that does not mean that there is an erasure of the mental structure that conditions the local reality based on its assumptions of symbolic reproduction. Instead, it is a mixture, with unpredictable moments of the prevalence of different trends - which may or may not confirm the others. This overlap between structural and conjunctural factors can offer an interesting view of some moments in the history of a society and a state. 
In the Brazilian case, political culture is permeated by an authoritarian and personalist social imaginary. However, the moment experienced in this second decade of the 21st century has some peculiarities. There is a specific democratic gap, which can be analyzed by recognizing some assumptions that support it. First, this gap originates from problems in the social modernization process. A process that is, on the one hand, incomplete, on the other, intense. This phenomenon has an impact on civic culture and how citizens' political participation develops. Second, from another point of view, this gap is the result of Brazilian political culture that is characterized, among other aspects, by the authoritarian bias, that is, by the detachment from the assumptions of the rule of law.

Brazil experienced an intense process of social modernization in the period between 1994 and 2014. However, it was an ambiguous process. On the one hand, there was economic development, re-democratization, consolidation of emancipatory values, and the creation of institutional mechanisms for political participation. On the other hand, there was a reduction in social associative involvement. As a result, a complex civic culture (characterized by an authoritarian social imaginary) was maintained, and the problem of sharp social inequality was not solved. This situation is based on a structural socio-economic status participation gap, which was not corrected by the best phase of the social modernization process.

As of 2015, the incomplete modernization process added to the recent Brazilian economic crisis fostered the emergence of a period of intense and rapid institutional, political and cultural setbacks. Both within the State and inside civil society, it is possible to observe a phenomenon back in the past, with the resurgence of authoritarian practices contrary to fundamental rights. Then, a favorable environment emerges for fundamentalist groups (notably religious), which is harmful to vulnerable groups (such as gays, blacks, women, and the poor). A new right-wing populism challenges the rule of law established by the 1988 Constitution. It is a new populism, different from previous Brazilian versions, and more easily explained by Ernesto Laclau's interpretation than by the classical perspective (of modernization theories) or even more recent ones, such as those inspired by Edward Thompson (BATISTELA, 2020). 
Therefore, implementing the principle of equality between citizens and the consolidation of the process of social modernization in contradictory countries like Brazil becomes a complicated task. In developing countries, the social modernization process has negative externalities resulting from the maintenance of inequality. On the other hand, democracy has inherent weaknesses, such as promoting a more critical and assertive society, turning against democracy itself. This weakness is, however, its greatest virtue: its enlightenment effect.

The re-democratization process in Brazil produced beneficial effects in transforming its society (notably the youngest), creating a more assertive public. However, this is a controversial process. In addition, Brazilians are subject to substantial political inequality resulting from the disparity of resources. It is not a reality favorable to the development of democratic values. Besides, institutional instability and fear of violence are factors that contribute to the setback. Finally, the transformation to the digital society also directly impacts democracy. It does not mean the internet itself is an inhibiting factor for political integration. However, in times of crisis and ideological polarization, virtual social networks can be an element of radicalization that is contrary to the assumptions of democracy.

Starting from the idea that civic culture influences democracy, and this, in turn, impacts civic culture, Brazil today is in a significant institutional, political, and cultural crisis. Contrary to what one would imagine some years ago, the Brazilian process of social modernization is strongly threatened in its most essential conquests, implying a menace to the values that support democracy like the rule of law and fundamental rights.

\section{References}

AGÊNCIA DE NOTÍCIAS. PNAD Contínua TIC 2017: Internet chega a três em cada quatro domicilios do país. 2018. Retrieved from:

https://agenciadenoticias.ibge.gov.br/agencia-sala-de-imprensa/2013-agenciade-noticias/releases/23445-pnad-continua-tic-2017-internet-chega-a-tres-emcada-quatro-domicilios-do-pais Access: 05 May 2018. 
ALENCAR, Gustavo. Alencar. Evangélicos e a Nova Direita no Brasil: os discursos conservadores do "neocalvinismo" e as interlocuções com a política. Teoria e cultura. v. 13 n. 2, 2018.

ALMOND, Gabriel; VERBA, Sidney. The Civic Culture. Princeton: Princeton University Press, 1963.

ANDERSON, Perry. Balanço do neoliberalismo. In: SADER, Emir; GENTILI, Pablo. Pós-neoliberalismo: as políticas sociais e o Estado democrático. 4. ed. Rio de Janeiro: Paz e Terra, 1995.

ANSART, Pierre. A gestão das paixões políticas. Tradução de Jacy Seixas. Curitiba: Editora da UFPR, 2019.

ANDUIZA, Eva; JENSEN, Michael; JORBA, Laia (Eds.). Digital Media and Political Engagement Worldwide: A Comparative Study. Cambridge: Cambridge University Press, 2012.

ARAUJO, Marcelo Henrique de. Evidenciando as desigualdades digitais: uma análise da influência da autonomia de uso e habilidades digitais no aproveitamento de oportunidades online [tese]. São Paulo: Faculdade de Economia, Administração e Contabilidade, 2019.

AVRITZER, Leonardo. O pêndulo da democracia no Brasil: uma análise da crise de 2013-2018. Novos Estudos - CEBRAP, São Paulo, v. 37, n. 02, pp. 273-289, maio-ago. 2018.

BAQUERO, Marcelo; RANINCHESKI, Sonia; CASTRO, Henrique C. de O. de. A formação política e o processo de democracia inercial. Revista Debates, Porto Alegre, v. 12, n. 1, p. 87-106, jan.-abr. 2018.

BERSTEIN, Sérgio. Culturas políticas e historiografia. In: AZEVEDO, Cecília et al. Cultura Política, Memória e Historiografia. Rio de Janeiro: FGV, p. 29-46, 2009.

BATISTELA, Alessandro. Reflexões acerca do conceito de populismo: da teoria clássica às contribuic,ões de Ernesto Laclau. Tempo e Argumento, Florianópolis, v. 12, n. 29, jan./abr. 2020.

BOAS, Taylor; SMITH, Amy Erica. Religion and the Latin American voter. In: CARLIN, Ryan E.; SINGER, Matthew M.; ZECHMEISTER, Elizabeth J. (Eds.). The Latin American voter. Pursuing representation and accountability in challenging contexts. Ann Arbor: University of Michigan Press, 2015. 
BOITO JR, Armando. Reforma e crise política no Brasil: os conflitos de classe nos governos do PT. São Paulo: UNESP, 2018.

BRENNAN, Jason. Against Democracy. Princeton: Princeton University Press, 2017.

BREPOHL, Marion; GONÇALVES, Marcos; GABARDO, Emerson. As violências do Estado de Exceção e a defesa da memória contra a invisibilidade dos grupos vulneráveis. Revista Brasileira de Estudos Políticos, Belo Horizonte. n. 117, p. $321-$ 361, jul.-dez. 2018.

BROOKS, Sarah. Insecure Democracy: Risk and Political Participation in Brazil. The Journal of Politics, v. 76, n. 4, p. 972-985, Oct. 2014.

BURITY, Joanildo. A onda conservadora na política brasileira traz o fundamentalismo ao poder? In: ALMEIDA, Ronaldo de; TONIOL, Rodrigo (Org.). Conservadorismos, fascismos e fundamentalismos: análises conjunturais. Campinas: Unicamp, 2018.

CAOZ-TSCHOPP, Marie Claire. Experiência Exílio/Desexílio e políticas de memória; questões à memória da insubmissão e da emancipação. In: GONÇALVES, Marcos; BREPOHL, Marion. Politicas de memória e experiências de (des) exílio. Curitiba: Editora da UFPR, 2019.

CARLIN, Ryan E.; SINGER, Matthew M.; ZECHMEISTER, Elizabeth J. Introduction to the Latin American voter. In: The Latin American voter. Pursuing representation and accountability in challenging contexts. Ann Arbor: University of Michigan Press, 2015.

CARVALHO, Augusto de. A estrutura ontológica do tempo presente. Tempo e Argumento, Florianópolis, v. 10, n. 24, p. 43 - 63, abr.-jun. 2018.

CARVALHO, Laura. Valsa Brasileira: do boom aos caos econômico. São Paulo: Todavia, 2018a.

CARVALHO, Lucas Borges. A democracia frustrada: fake News, política e liberdade de expressão nas redes sociais. Internet \& Sociedade. v. 1, n. 1, p. $172-$ 199, fev. 2020

CARVALHO, Maria Alice Rezende de. Cultura política, capital social e a questão do déficit democrático no Brasil. In: VIANNA, Luiz Werneck (Org.). A democracia e os três poderes no Brasil. Rio de Janeiro: IUPERJ, 2002. 
CHARTIER, Roger. Cultural history: between practices and representations. Translated by Lydia G. Cochrane. Cambridge: Polity/Blackwell, 1988.

CODATO, Adriano. A nova direita; uma análise da dinâmica partidária e eleitoral do campo conservador. 10 Encontro Ciência Política, Memória e Futuro. Belo Horizonte: Associação Brasileira de Ciência Política. 2006. Retrieved from: https://www.researchgate.net/publication/281269137_A_nova_direita_brasileira_ uma_analise_da_dinamica_partidaria_e_eleitoral_do_campo_conservador_The_ brazilian_new_right Access: 09 Jun. 2021.

CORREAS, Óscar. El neoliberalismo en el imaginario jurídico. In: MARQUES NETO, Agostinho Ramalho et al. (Ogs.). Direito e neoliberalismo: elementos para uma leitura interdisciplinar. Curitiba: EDIBEJ, 1996.

DAHL, Robert; Shapiro, Ian. On Democracy. New Haven: Yale University Press, 2015.

DALLARI, Dalmo de A. Sociedade, Estado e Direito: a caminhada brasileira ruma ao século XXI. In: MOTA, Carlos Guilherme. (Org.). Viagem incompleta: a experiência brasileira. São Paulo: SENAC-SP, 2000.

DALTON, Russel. Citizen Attitudes and political behavior. Comparative Political Studies. v. 33, n. 6-7, p. 912-940, Aug.-Sep. 2000.

DALTON, Russell. Democracy's Dilemma: The Widening Participation Gap and its Consequences. Oxford: Oxford University Press, $2017 \mathrm{.}$.

DALTON, Russell. Political Realignment: economics, culture, and electoral change. Oxford: Oxford University Press, 2018.

DALTON, Russell. Political support in advanced industrial democracies. CDS Working Papers. Jan. 1998. Retrieved from:

https://escholarship.org/uc/item/8281d6wt. Access: 12 Apr. 2020.

DALTON, Russell. The Participation Gap: social status \& political inequality. Oxford: Oxford University Press, 2017b.

DALTON, Russell; KITTELSON, Miki C. Virtual Civil Society in the United States and Australia. Australian Journal of Political Science, v. 47, n. 1, p. 11-29, Mar. 2012.

DALTON, Russell; WELZEL, Christian (Eds.). The civic culture transformed: from allegiant to assertive citizens. Cambridge University Press, 2014. 
DALY, Tom. Populism, Public Law, and Democratic Decay in Brazil: Understanding the Rise of Jair Bolsonaro March 11, 2019. 14th International Human Rights Researchers' Workshop: 'Democratic Backsliding and Human Rights. Law and Ethics of Human Rights (LEHR) Journal, 2-3 Jan. Retrieved from: SSRN: https://ssrn.com/abstract=3350098 Access: 20 May 2020.

DARDOT, Pierre; LAVAL, Christian. A nova razão do mundo: ensaio sobre a sociedde neoliberal. Tradução de Mariana Echalar. São Paulo: Boitempo, 2016.

DATAREPORTAL. Digital 2019: Brazil. Retrieved from: https://datareportal.com/reports/digital-2019-brazil. Access: 12 Apr. 2020.

DAVIS, Stuart; STRAUBHAAR, Joe. Producing Antipetismo: Media activism and the rise of the radical, nationalist right in contemporary Brazil. The International Communication Gazette, v. 82, n. 1, p. 82-100, 2020.

DOWS, Anthony. An Economic Theory of Democracy. New York: Harper \& Row, 1965.

DTCOM. Inclusão Digital Brasil. Retrieved from: https://dtcom.com.br/inclusaodigital-brasil/ 2017. Access em: 04 mai. 2020.

EASTON, David. A reassessment of the concept of political support. British Journal of Political Science, n. 5, p. 435-457, 1975.

FUKS, Mario Fuks; CASALECCHI, Gabriel Avila; GONÇALVES, Guilherme Quaresma; DAVID, Flávia Felizardo. Qualificando a adesão à democracia: quão democráticos são os democratas brasileiros? Revista Brasileira de Ciência Política, Brasília, n.19. p. 199-219, jan.-abr. 2016.

GABARDO, Emerson. Estado Social e Estado Subsidiário: dois modelos distintos de desenvolvimento. Revista de Direito Administrativo e Infraestrutura. Belo Horizonte, v. 11, n. 3, p. 283-299, 2019.

GABARDO, Emerson. O Princípio da Supremacia do Interesse Público sobre o Interesse Privado como fundamento do Direito Administrativo social. Revista de Investigações Constitucionais, Curitiba, v. 4, n. 2, p. 95-130, maio-ago. 2017.

GABARDO, Emerson. Os perigos do moralismo político e a necessidade de defesa do direito posto na Constituição da República de 1988. A\&C - Revista de Direito Administrativo \& Constitucional, Belo Horizonte, a. 17, n. 70, p. 65-91, out.-dez. 2017. 
GARCÍA OLIVA, Javier. Brexit, Human Rights and the Role of Constitutional Culture. Revista de Investigações Constitucionais, Curitiba, v. 6, n. 3, p. 573-594, set.-dez. 2019.

GEST, Justin; Tyler, Reny; Mayer, Jeremy. Roots of the radical right: nostalgic deprivation in the United States and Britain. Comparative Political Studies, 2017.

GINZBURG, Jaime. Crítica em tempos de violência. São Paulo: Editora da Universidade de São Paulo, 2012.

GIRARDET, Raoul. Mitos e mitologias políticas. Tradução de Maria Lúcia Machado. São Paulo: Companhia das Letras, 1987.

GOHN, Maria da Glória (Org.). Movimentos sociais no século XXI. 3.ed. Petrópolis: vozes, 2007.

HACHEM, Daniel Wunder. A noção constitucional de desenvolvimento para além do viés econômico: reflexos sobre algumas tendências do Direito Público brasileiro. A\&C - Revista de Direito Administrativo \& Constitucional, Belo Horizonte, a. 13, n. 53, p. 133-168, jul.-set. 2013.

HOBSBAWN, Eric. Globalização, Democracia e Terrorismo. Tradução de José Viegas. São Paulo: Companhia das Letras, 2007.

IANONI, Marcus. Políticas Públicas e Estado: o Plano Real. Lua Nova: Revista de Cultura e Política. n. 78, pp. 143-183, 2009.

INGHAM, Sean; LEVIN, Ines. Can deliberative minipublics influence public opinion? Theory and experimental evidence. SSRH. Jan. 2017.

INGLEHART, Ronald. Cultural evolution: People's motivations are changing and reshaping the world. Cambridge: Cambridge University Press, 2018.

INGLEHART, Ronald. Democracy and Happiness: What Causes What? In: Happiness, Economics, and Politics: Towards a Multi-Disciplinary Approach. Northampton: Edward Elgar Publishing Ltd., 2009.

JAKOBSEN, Tor Georg; LISTHAUG, Ola. Social Change and the Politics of Protest. In: DALTON, Russell; WELZEL, Christian (Eds.). The civic culture transformed: from allegiant to assertive citizens. Cambridge University Press, 2014.

KREUZ, Letícia Camargo; VIANA, Aguilar, Ana. 4a Revolução Industrial e governo digital: exame de experiências implementadas no Brasil. Revista Eurolatinoamericana De Derecho Administrativo. v. 5, n. 2, p. 267-286, 2018. 
KUSCHNIR, Karina; CARNEIRO, Leandro Piquet. As dimensões subjetivas da política: cultura política e antropologia política. Estudos Históricos, n. 24, p. $227-$ 250, 1999.

LEVENDUSKY, Mattew S. Why do partisan media polarize viewers? American Journal of Political Science, v. 3, n. 57, 611-623, 2013.

LONDOÑO, Ernesto; ANDREONI, Manuela; CASADO, Letícia. Bolsonaro, Isolated and Defiant, Dismisses Coronavirus Threat to Brazil. The New York Times. April 1, 2020. Retrieved from:

https://www.nytimes.com/2020/04/01/world/americas/brazil-bolsonarocoronavirus.html. Access: 05 Apr. 2020.

LUPIA, Arthur; MCCUBBIN, Mathew. The Democratic Dilemma: Can Citizens Learn What They Need to Know? New York: Cambridge University Press, 1998.

MBEMBE, Achille. Necropolítica: biopoder, soberania, estado de exceção, política da morte. Tradução de Renata Santini. São Paulo: N. 1, 2018.

MENDONÇA, Ricardo Fabrino; AMARAL, Ernesto F. L. Racionalidade online: provimento de razões em discursos virtuais. Opinião Pública, Campinas, v. 22, n. 2, p. 418-445, ago. 2016.

MENDONÇA, Ricardo Fabrino; BUSTAMANTE, Márcio. Back to the Future: Changing Repertoire in Contemporary Protests. Bulletin of Latin American Research, v. 39, p. 1-15, 2020.

MENDONÇA, Ricardo Fabrino; LAVALLE, Adrian Gurza. Brazil, 40 Years of Struggles Over Political Legitimacy Through the Lenses of Representation. Representation - Journal of Representative Democracy. v. 55. n. 3, p. 239-250, 2019.

MISHLER, William; ROSE, Ricard. What are the origins of political trust? Testing Institutional and Cultural Theories in Post-Communist Societies. Comparative Political Studies, v. 34, n. 1, p. 30-62, Feb. 2001,

MOISÉS, José Álvaro. Cultura política, instituições e democracia: lições da experiência brasileira. Revista Brasileira de Ciências Sociais, v. 23, n. 66, fev. 2008.

MORAIS, Jennifer Azambuja; BAQUERO, Marcello. A internet e a (des)politização dos jovens brasileiros. Revista Cadernos de Campo, Araraquara, n. 25, p. 33-62, jul.-dez. 2018. 
MOTTA, Rodrigo Patto Sá. Cultura política e ditadura: um debate teórico e historiográfico. Tempo \& Argumento, Florianópolis, v. 10, n. 23, p. 109-137, jan.mar. 2018.

MOTTA, Rodrigo Patto Sá. Desafios e dificuldades na apropriação de cultura política pela historiografia. In: MOTTA, Rodrigo Patto Sá (Org.). Culturas Políticas na História: novos estudos. 2. ed. Belo Horizonte: Fino Traço, 2014.

MÜLLER, Edward N.; SELIGSON, Mitchell A. Civic culture and democracy: the question of causal relationships. American Political Science Review, v. 88, n. 3, Sep. 1994.

MUNIZ, Cibele Cristina Baldassa. Participação democrática na administração pública: audiências e consultas públicas na Lei 9.784/99. 2018. Universidade de São Paulo, São Paulo, 2018.

NACHTWEY, Oliver. Descivilização - Sobre tendências regressivas nas sociedades ocidentais. In: APPADURAI, Arjun. A grande regressão: um debate internacional sobre os novos populismos - e como enfrentá-los. São Paulo: Estação Liberdade, 2019.

NEVITTE, Neil. The decline of deference revisited: evidence after twenty-five years. In: DALTON, Russell; WELZEL, Christian (Eds.). The civic culture transformed: from allegiant to assertive citizens. Cambridge University Press, 2014.

NORRIS, Pippa. Derecha Radical: Votantes y partidos políticos em el mercado electoral. Madrid: Akal, 2009.

OLIVEIRA, Francisco. Neoliberalismo à brasileira. In: SADER, Emir; GENTILI, Pablo. Pós-neoliberalismo: as políticas sociais e o Estado democrático. 4. ed. Rio de Janeiro: Paz e Terra, 1995.

OLSON, Mancur. The logic of collective action. Cambridge, MA: Harvard University Press, 1965.

PEIXOTO, Vitor de Moraes; SOUZA, Jessica Matheus de. Condicionantes da tolerância no Brasil contemporâneo. SOnline - Revista Eletrônica de ciências sociais, n. 30, 2019.

PEREIRA, Luiz Carlos Bresser. Reforma do Estado parea a cidadania: a reforma gerencial brasileira na perspectiva internacional. São Paulo: Ed. 34, 1998. 
PÉREZ, Orlando J. The Impact of Crime on Voter Choice in Latin America. In: CARLIN, Ryan E., SINGER, Matthew M., ZECHMEISTER, Elizabeth J. (Eds.). The Latin American voter. Pursuing representation and accountability in challenging contexts. Ann Arbor: University of Michigan Press, 2015.

PINHEIRO, Paulo Sérgio. Transição política e não-Estado de Direito na república. In: Sachs, Ignacy; Wilheim, Jorge; Pinheiro, Paulo Sérgio (Orgs.). Brasil: um século de transformações. São Paulo: Companhia das Letras, 2001.

PINHEIRO-MACHADO, Rosana. Amanhã vai ser maior. o que aconteceu com o Brasil e possíveis rotas de fuga para a crise atual. São Paulo: Planeta do Brasil, 2019.

PINTO, Céli Regina Jardim. Tempos de pós-democracia: auséncia do povo. [Debate]. Revista Tempo e Argumento, Florianópolis, v. 9, n. 21, p. 472 - 481, mai.-ago. 2017.

POPKIN, Samuel. The Reasoning Voter: Communication and Persuasion in Presidential Campaigns. Chicago: University of Chicago Press, 1991.

POSNER, Richard. Economic Analysis of Law. 8. ed., New York: Aspen Publishers, 2011.

PUTNAM, Robert D.; SANDER, Thomas H. Democracy's Past and Future: Still Bowling Alone? - The Post-9/11 Split. Journal of Democracy, v. 21, n. 1, p. 9-16, Jan. 2010.

PYE, Lucian; VERBA, Sidney (Eds.). Political Culture and Political Development. Princeton: Princeton University Press, 1965.

RABELO FILHO, José V. A construção social do golpe de 31 de março de 1964: memória e imaginário social. Anais do XXVII Simpósio Nacional de História: conhecimento histórico e diálogo social. Natal, 2013. Retrieved from: http://www.snh2013.anpuh.org/resources/anais/27/1364755719_ARQUIVO_ANPU H2013.pdf Acces: 19 Mar. 2020.

RENNÓ, Lucio R. Desigualdade e Informação Política: As Eleições Brasileiras de 2002. Dados - Revista de Ciências Sociais, Rio de Janeiro, v. 50, n. 4, p. 721-755, 2007.

RENNÓ, Lucio R. Validade e Confiabilidade das Medidas de Confiança Interpessoal: O Barômetro das Américas. Dados - Revista de Ciências Sociais, Rio de Janeiro, v. 54, no 3, p. 391 a 428, 2011. 
RIBEIRO, Ednaldo; FUKS, Mario. Tolerância política no Brasil. Opinião Pública, v. 25, n. 3, Campinas, p. 531-555, nov.-dez. 2019.

ROSENBERG, Shawn W. Democracy Devouring Itself: The Rise of the Incompetent Citizen and the Appeal of Right-Wing Populism. In: HUR, Domenico Uhng; SABUCENO, José Manuel (Eds.). Psychology of Political and Everyday Extremism. UC Irvine. 2020. p. 3. Retrieved from: https://escholarship.org/uc/item/8806z01m . Access: 14 Apr. 2020.

ROZNAI, Yaniv; BRANDES, Tamar Hostovsky. Democratic Erosion, Populist Constitutionalism, and the Unconstitutional Constitutional Amendments Doctrine. Law \& Ethics of Human Rights, v. 14, n. 1, p. 19-48, 2020.

SADER, Emir. A hegemonia neoliberal na América Latina. In: SADER, Emir; GENTILI, Pablo. Pós-neoliberalismo: as políticas sociais e o Estado democrático. 4. ed. Rio de Janeiro: Paz e Terra, 1995.

SALGADO, Eneida Desiree. A Series of Unfortunate Events or Some Karma? 2018 Election and Brazil's Persistent Conservative Alignment. UC Irvine: CSD Working Papers. 2021. Retrieved from: https://escholarship.org/uc/item/04w053fg Access: 01 Jun. 2021.

SALGADO, Eneida Desiree. Constituição e Democracia: tijolo por tijolo em um desenho (quase) lógico - vinte anos de construção do projeto democrático brasileiro. Belo Horizonte: Fórum, 2007.

SALGADO, Eneida Desiree. Princípios constitucionais eleitorais. Belo Horizonte: Fórum, 2010.

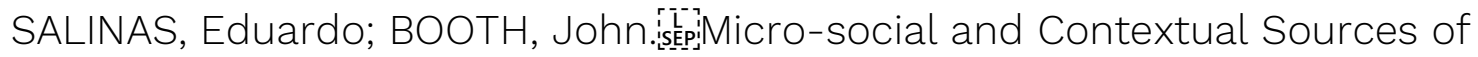
Democratic Attitudes in Latin America. Journal of Politics in Latin America, v. 3, n. 1, p. 29-64, 2011.

SANTOS, Queila Rocha Carmona; BUCCI, Alexandre. Direitos humanos e breves notas a respeito do direito à memória e do direito à verdade. In: SILVEIRA, Vladimir Oliveira da; LOPES, Ana Maria D’Ávila; SPOSATO, Karyna Batista (Coords.). Direito internacional dos direitos humanos. Florianópolis: CONPEDI, 2015.

SELIGSON, Mitchell A.; BOOTH, John A. Political Participation in Latin America: An Agenda for Research. Latin American Research Review, v. 11, n. 3, p. 95-119, 1976. 
SILVA, Marco Aurélio Souza da. Cidadania: uma incursão teórico-conceitual pelas suas dimensões. A\&C - Revista de Direito Administrativo \& Constitucional, Belo Horizonte, a. 15, n. 59, p. 151-175, Jan.-Mar. 2015.

SINGER, André. O lulismo em crise: um quebra-cabeça do período Dilma (20112016). São Paulo: Companhia das Letras, 2018.

SINGER, André. Os sentidos do lulismo: reforma gradual e pacto conservador. São Paulo: Companhia das Letras, 2012.

SKIDMORE, Thomas E. Uma história do Brasil. Translation by Raul Fiker. 3. ed. São Paulo: Paz e Terra, 1998.

STRAUSS, Claudia. The Imaginary. Anthropological Theory, v. 6. n. 3, p. 322-344, 2006.

TEMER, Michel. Discurso de Posse. In: Folha de S.Paulo. 12 maio 2016. Retrieved from: http://www1.folha.uol.com.br/poder/2016/05/1770780-leia-integra-dodiscurso-de-posse-do-presidente-interino-michel-temer.shtml Access: 21 Mar. 2020.

THE EDITORS. Introducing History of the Present. History of the Present. v. 1, n. 1, 2011, pp. 1-4. Retrieved from:

www.jstor.org/stable/10.5406/historypresent.1.1.0001. Access: 16 Apr. 2020.

TOURAINE, Alain. Crítica da modernidade. 4. ed. Tradução de Elia Ferreira Edel. Petrópolis: Vozes, 1997.

UNITED NATIONS. UN. E-government survey 2016: e-government in support of sustainable development. 2017. Retrieved from:

http://workspace.unpan.org/sites/Internet/Documents/UNPAN96407.pdf Access: 03 May 2020.

VALIM, Rafael. Estado de exceção: a forma jurídica do neoliberalismo. São Paulo: Contracorrente, 2017.

VERBA, Sidney; SCHOLOZMAN, Kay; BRADY, Henry. Voice and Political Equality. Cambridge: Harvard University Press, 1995.

VIANA, Ana Cristina Aguilar; KREUZ, Letícia Regina Camargo. Interesse Público. v. 20, n. 110, p. 51-68, Jul./Ago. 2018. 
VIANNA, Luiz Fernando. Polícia de Witzel é máquina de matar e mentir. assassinatos de quatro jovens inocentes mostram como estratégia do governador é inútil e genocida. Exame. 14 Ago. 2019. Retrieved from:

https://exame.abril.com.br/brasil/oab-emite-nota-de-repudio-a-declaracao-dewitzel/ Access: 18 Mar. 2020.

WACQUANT, Loïc. La fabrique de l 'ètat neoliberal: workfare, , prisonfare, et insecurité sociale. In: BRUGẺRE, Fabienne et al. Le nopuvel esprit du libéralisme. Paris: Le Bordeaul d'Eau, 2011.

WELSH, Stephen. The Theory of Political Culture. Oxford: Oxford University Press, 2013.

WELZEL, Christian; ALVAREZ, Alexandro Moreno. Enlightening people: the spark of emancipative values. In: DALTON, Russell; WELZEL, Christian (Eds.). The civic culture transformed: from allegiant to assertive citizens. Cambridge University Press, 2014.

WELZEL, Christian; INGLEHART, Ronald. Human development and the explosion of democracy: variations of regime change across 60 societies. Berlin: Veröffentlichungsreihe der Abteilung Institutionen und Sozialer Wandel des Forschungsschwerpunkts Sozialer Wandel, Institutionen und Vermittlungsprozesse des Wissenschaftszentrums Berlin für Sozialforschung, n. FS III, 01-202, 2001. 